\title{
PROGNOSIS FOR THE NEWBORN FROM MULTIPLE PREGNANCY
}

\author{
R. OSUCH-JACZEWSKA, O. LEMPART, Z. OCHABSKA
}

Department of Obstetrics and Gynecology, Silesian Academy of Medicine, Bytom, Poland

A total of 669 newborns from multiple pregnancies, including 15 triplets, bave been examined. Full-term fetuses were $19.3 \%$ premature ones $60.7 \%$, and dystrophic ones $20 \%$. Of these, $58.4 \%$ were born in good conditions, 25.1\% in average conditions (4-7 Apgar scores), and $16.4 \%$ in bad conditions (1-3 Apgar scores). Complications in the neonatal period were reported in $38.7 \%$ of cases (respiratory syndrome $21.2 \%$, CNS injury $4.8 \%$, developmental defects $1.3 \%$, other complications $9.3 \%$ ).

Twin mortality amounted to $10.5 \%$, mainly due to bypoxemia $(7.2 \%)$, cerebral lesion $(2.4 \%)$, developmental defects $(0.4 \%)$, and general edema $(0.5 \%)$.

Prognosis for a newborn from multiple pregnancy is a very controversial subject in the literature and there are conflicting attitudes especially with regard to the risks threatening the first and second twin, their mortality or development. Some feel that both twins are exposed to the same hazards (Graves et al. 1962), while others think that the chance of survival is greater for the first than for the second twin (Carston 1957, Lister 1958); numerous reports indicate a higher incidence of damages and mortality in the second twin (Spurway 1962, Slomko and Kuczynski 1965a, Skalba et al. 1972).

The purpose of this study is to analyse the conditions of twins after delivery during their neonatal period, and their mortality with reference to a series of factors (degree of asphyxia, maturity, sex, weight).

An analysis was undertaken of the development of 669 newborns from multiple pregnancies, including 15 triplets, born from 1962 to 1972 in the 2nd Clinic of Obstetrics and Gynecology of the Silesian Academy of Medicine in Bytom. Conditions of the infants after birth were assessed according to the Apgar score, while the degree of maturity was determined by means of the scheme by Farr et al. (1966). Conclusions on the neonatal development were drawn from clinical observations, neurological and auxiliary examinations.

\section{RESULTS}

Table 1 shows that there were 358 same-sex twins (53.5\%) and 311 opposite-sex ones. Mortality in same-sex twins is $7.0 \%$ higher than in opposite-sex ones. Table 2 gives the deaths of first and second twins according to birth weight. Mortality in infants with a low birth weight accounts for $17.9 \%$ and it rises in line with the decreasing weight of the fetus from $1500 \mathrm{~g}$ down, the death of the second twin occurring $8.4 \%$ more frequently. 
Table 1. Neonatal Mortality in Twins by Sex

\begin{tabular}{|c|c|c|c|c|c|c|}
\hline & \multicolumn{2}{|c|}{ Females } & \multicolumn{2}{|c|}{ Males } & \multicolumn{2}{|c|}{ Total } \\
\hline & $N$ & $\%$ & $N$ & $\%$ & $N$ & $\%$ \\
\hline \multicolumn{7}{|c|}{ Same-sex pairs $[\mathrm{N}=358]$} \\
\hline $\begin{array}{l}\text { Survival } \\
\text { Deaths }\end{array}$ & $\begin{array}{r}147 \\
21\end{array}$ & $\begin{array}{l}87.50 \\
12.5\end{array}$ & $\begin{array}{r}132 \\
26\end{array}$ & $\begin{array}{l}83.5 \\
16.5\end{array}$ & $\begin{array}{r}279 \\
47\end{array}$ & $\begin{array}{l}85.6 \\
14.4\end{array}$ \\
\hline Total & 168 & 51.5 & 158 & 48.5 & 326 & 100.0 \\
\hline \multicolumn{7}{|c|}{ Opposite-sex pairs $[\mathrm{N}=311]$} \\
\hline $\begin{array}{l}\text { Survival } \\
\text { Deaths }\end{array}$ & $\begin{array}{r}147 \\
14\end{array}$ & $\begin{array}{r}91.3 \\
8.7\end{array}$ & $\begin{array}{r}122 \\
9\end{array}$ & $\begin{array}{r}93.1 \\
6.9\end{array}$ & $\begin{array}{r}269 \\
23\end{array}$ & $\begin{array}{r}92.1 \\
7.4\end{array}$ \\
\hline Total & 161 & 55.1 & 131 & 44.9 & 292 & 100.0 \\
\hline
\end{tabular}

Note: Twins born below $1000 \mathrm{~g}(16 \mathrm{~F}+16 \mathrm{M}$ same-sex, and $13 \mathrm{~F}+6 \mathrm{M}$ opposite-sex) are excluded.

Table 2. Twin Mortality in Relation to Birth Order and Weight

\begin{tabular}{|c|c|c|c|c|c|c|c|c|c|}
\hline \multirow{2}{*}{ Weight } & \multicolumn{3}{|c|}{ First twin } & \multicolumn{3}{|c|}{ Second twin } & \multicolumn{3}{|l|}{ Total } \\
\hline & $\mathrm{N}$ & Deaths & $\%$ & $\mathbf{N}$ & Deaths & $\%$ & $\mathrm{~N}$ & Deaths & $\%$ \\
\hline$<1000$ & 26 & 25 & 96.1 & 25 & 24 & 96.0 & 51 & 49 & 96.0 \\
\hline $\begin{array}{l}1001-1250 \\
1251-1500 \\
1501-2000 \\
2001-2250\end{array}$ & $\begin{array}{l}13 \\
25 \\
53 \\
98\end{array}$ & $\begin{array}{r}7 \\
11 \\
6 \\
2\end{array}$ & $\begin{array}{r}53.8 \\
44.0 \\
11.3 \\
2.0\end{array}$ & $\begin{array}{l}12 \\
23 \\
68 \\
77\end{array}$ & $\begin{array}{r}8 \\
16 \\
16 \\
-\end{array}$ & $\begin{array}{l}66.6 \\
69.6 \\
23.5 \\
-\end{array}$ & $\begin{array}{r}25 \\
48 \\
121 \\
175\end{array}$ & $\begin{array}{r}15 \\
27 \\
22 \\
2\end{array}$ & $\begin{array}{r}60.0 \\
56.0 \\
18.2 \\
1.1\end{array}$ \\
\hline Total & 189 & 26 & 13.8 & 180 & 40 & 22.2 & 369 & 66 & 17.9 \\
\hline $\begin{array}{l}2251-2500 \\
2501-3000 \\
>3000\end{array}$ & $\begin{array}{l}48 \\
52 \\
19\end{array}$ & - & - & $\begin{array}{l}54 \\
46 \\
30\end{array}$ & $\begin{array}{r}4 \\
-\end{array}$ & $\begin{array}{l}7.4 \\
-\end{array}$ & $\begin{array}{r}102 \\
98 \\
49\end{array}$ & $\begin{array}{l}4 \\
-\end{array}$ & 3.9 \\
\hline Total & 119 & - & - & 130 & 4 & 3.0 & $249(37.3)$ & 4 & 1.6 \\
\hline Grand total & 334 & 51 & 15.3 & 335 & 68 & 20.3 & 669 & 119 & 17.8 \\
\hline
\end{tabular}


Mortality in infants with birth weight exceeding $2250 \mathrm{~g}$ is $1.6 \%$ and concerns the second twin only.

The correlation of the condition of the newborns after delivery assessed by Apgar score, by degree of maturity and course of the infancy period, is presented in Table 3, showing that full-term fetuses were $19.3 \%$, premature ones $60.7 \%$, and dystrophic ones $20.0 \%$. At birth $58.4 \%$ of them were in good conditions, $25.1 \%$ in average conditions (4-7 As), and $16.4 \%$ in bad conditions $(1-3 \mathrm{As})$. Of these, $88.1 \%$ were premature, $10.0 \%$ dystrophic, and $1.8 \%$ at-term twins; $6.4 \%$ from this group died.

Table 3. Course of Neonatal Period and Newborn Conditions

\begin{tabular}{|c|c|c|c|c|c|c|}
\hline & & \multicolumn{3}{|c|}{ Apgar score } & \multirow{2}{*}{ Total } & \multirow{2}{*}{ Deaths } \\
\hline & & $1-3$ & $4-7$ & $8-10$ & & \\
\hline On term & $\begin{array}{l}\mathrm{N} \\
\%\end{array}$ & $\begin{array}{l}2 \\
1.8\end{array}$ & $\begin{array}{l}9 \\
5.3\end{array}$ & $\begin{array}{l}118 \\
30.2\end{array}$ & $\begin{array}{l}129 \\
19.3\end{array}$ & - \\
\hline Small-for-dates & $\begin{array}{l}\mathrm{N} \\
\%\end{array}$ & $\begin{array}{l}11 \\
10.0\end{array}$ & $\begin{array}{l}17 \\
10.1\end{array}$ & $\begin{array}{l}106 \\
27.1\end{array}$ & $\begin{array}{l}134 \\
20.0\end{array}$ & $\begin{array}{l}16 \\
11.9\end{array}$ \\
\hline Premature & $\begin{array}{l}\mathrm{N} \\
\%\end{array}$ & $\begin{array}{l}97 \\
88.1\end{array}$ & $\begin{array}{l}142 \\
84.5\end{array}$ & $\begin{array}{l}167 \\
42.7\end{array}$ & $\begin{array}{l}406 \\
60.7\end{array}$ & $\begin{array}{l}54 \\
13.3\end{array}$ \\
\hline Total & $\begin{array}{l}\mathrm{N} \\
\%\end{array}$ & $\begin{array}{l}110 \\
16.4\end{array}$ & $\begin{array}{l}168 \\
25.1\end{array}$ & $\begin{array}{l}391 \\
58.4\end{array}$ & $\begin{array}{l}669 \\
100.0\end{array}$ & $\begin{array}{l}70 \\
10.5\end{array}$ \\
\hline \multicolumn{7}{|l|}{ Course of neonatal period } \\
\hline Uncomplicated & $\begin{array}{l}\mathrm{N} \\
\%\end{array}$ & - & 37 & 373 & $\begin{array}{l}410 \\
61.3\end{array}$ & - \\
\hline Complicated & $\begin{array}{l}\mathrm{N} \\
\%\end{array}$ & 110 & 131 & 18 & $\begin{array}{l}259 \\
38.7\end{array}$ & - \\
\hline Respiratory syndrome & $\begin{array}{l}\mathrm{N} \\
\%\end{array}$ & 68 & 79 & 5 & $\begin{array}{l}142 \\
21.2\end{array}$ & $\begin{array}{l}48 \\
7.2\end{array}$ \\
\hline Congenital malformation & $\begin{array}{l}\mathrm{N} \\
\%\end{array}$ & 2 & 4 & 3 & $\begin{array}{l}9 \\
1.3\end{array}$ & $\begin{array}{l}3 \\
0.4\end{array}$ \\
\hline Cerebral lesion & $\begin{array}{l}\mathrm{N} \\
\%\end{array}$ & 20 & 12 & - & $\begin{array}{l}32 \\
4.8\end{array}$ & $\begin{array}{l}16 \\
2.4\end{array}$ \\
\hline Hydrops universalis & $\begin{array}{l}\mathrm{N} \\
\%\end{array}$ & 2 & - & - & $\begin{array}{l}2 \\
0.3\end{array}$ & $\begin{array}{l}3 \\
0.5\end{array}$ \\
\hline M. hemoliticus neonat. & $\mathrm{N}$ & - & 2 & - & 2 & \\
\hline Others & $\begin{array}{l}\mathrm{N} \\
\%\end{array}$ & 18 & 34 & 10 & $\begin{array}{l}62 \\
9.3\end{array}$ & \\
\hline Deaths & $\begin{array}{l}N \\
\%\end{array}$ & $\begin{array}{l}43 \\
6.4\end{array}$ & $\begin{array}{l}27 \\
4.0\end{array}$ & - & & $\begin{array}{l}70 \\
10.5\end{array}$ \\
\hline
\end{tabular}


Table 4. Congenital Malformations and Birith Order in Multiple Pregnancy

\begin{tabular}{|c|c|c|c|c|c|}
\hline Malformation & $\begin{array}{l}\text { Birth } \\
\text { order }\end{array}$ & W eight & Sex & Treatment & Deaths \\
\hline Chelioschisis & II & 1780 & $\mathrm{M}$ & operatory & - \\
\hline Teratoma & II & 3500 & $\mathrm{M}$ & operatory & - \\
\hline Congenital heart defect & I & 2300 & $\mathrm{M}$ & & - \\
\hline Congenital sight defect & II & 2100 & $\mathrm{M}$ & & - \\
\hline Acranius & III & 360 & $\mathrm{~F}$ & & - \\
\hline Congenital heart defect & I & 2160 & $\mathrm{~F}$ & & - \\
\hline 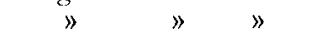 & I & 2800 & M & operatory & - \\
\hline$"$ & II & 2600 & M & & - \\
\hline$»$ & I & 1650 & M (from MF pair) & & — \\
\hline Down's syndrome " & I & 1900 & $\mathrm{M}$ & & + \\
\hline
\end{tabular}

Complications in the neonatal period occurred in $38.7 \%$, the most frequent being respiratory syndrome complications in infants born in bad and average conditions $(21.2 \%)$, CNS injury (4.8\%), developmental defects (1.3\%), and other complications $(9.3 \%)$.

Infant mortality was $10.5 \%$, the most frequent causes of death being hypoxemia $(7.2 \%)$, cerebral lesion upon delivery $(2.4 \%)$, developmental defects $(0.4 \%)$, and general edema $(0.5 \%)$. Table 4 shows the defects found in the twins.

\section{DISCUSSION}

Twin mortality in our own material attains $10.5 \%$ and is within the limits set by other authors (Anderson 1956, Lister 1958, Graves et al. 1962, Spurway 1962, Sparling 1964, Slomko and Kuczynski 1965, Statistical Atlas on Public Health 1970). Mortality is significantly high in same-sex twins (13.4), and opposite-sex twins (7.4\%). Similar data are given by other authors too (Slomko and Kuczynski 1965a, Statistical Atlas on Public Heath 1970), while Sparling (1964) reports a difference of $14.1 \%$ between death rates of same-sex and opposite-sex twins. The above figures are justified by the irregularities of the umbilical cord and placenta. The percentage of the newborns with serious asphyxia in our material was $16.4 \%$, due to both prematurity $(88.1 \%$ ) and higher rate of occurrence of pregnancy and delivery complications $(8 \%)$.

Twin prematurity and dystrophy problems are extensively reported in the literature by many authors; they were shown to occur in $40.0-60.0 \%$ of cases (Lister 1958, Potter 1963, Slomko and Kuczynski 1965, Statistical Atlas on Public Health 1970). The high percentage of premature twins results into an extended stay of the infants in the Ward on the average up to 22 days. The longest hospital stay recorded for twins was 69 days, the twins were bisexual and had the lowest birth weight (780 and $890 \mathrm{~g})$ and they were successfully kept alive. We defined $60.7 \%$ of our newborns as premature and $20.0 \%$ as dystrophic. Weight differences exceeding $1000 \mathrm{~g}$ between the first and second twin were found in $2.1 \%$ of cases (Table 5). According to most authors (Potter 1963, Slomko and Kuczynski 1965a) these are mainly due to the pathology of placenta. 
Table 5. Weight Differences between First and Second Twin

\begin{tabular}{|c|c|c|}
\hline Difference $(\mathrm{g})$ & $N$ & $\%$ \\
\hline No difference & 172 & 51.8 \\
\hline$<300$ & 87 & 26.2 \\
\hline $301-500$ & 47 & 14.2 \\
\hline $501-1000$ & 19 & 5.7 \\
\hline$>1000$ & 7 & 2.1 \\
\hline 'Total & 160 & 48.2 \\
\hline
\end{tabular}

The neonatal period and twin mortality are closely related to the conditions after delivery, prematurity and dystrophy; the above newborns are described in the English literature as "risk children".

It is noteworthy that a high rate of malformations, up to $1.3 \%$, was found in the group of same-sex twins. In Potter's opinion premature delivery and developmental disorders are found more frequently in $M Z$ twins though their cause is not yet clear.

It may be concluded that the prognosis of a newborn from multiple pregnancy is closely related to prematurity and dystrophy, which contribute to the increasing complications during the neonatal period and the high twin mortality.

Dr. Rozalia Osuch-Jaczewska, Kochanowskiego 18, 40-035 Katowice, Poland. 